\title{
The Use of Literately Translation in Teaching of Russian
}

\author{
Hurshit Isayev, Hacali Necefoğlu \\ Kafkas University, Kars, Turkey
}

\begin{abstract}
The art of translation has a crucial role in developing relations between Turkish and Russian cultures and literatures. Translation, which is an acquaintance tool between humans, has played an important role in formating and developing many nations and peoples in time. Of course, the translation problems that appear in the development of the translation art which has an old history always make the scientists busy. The role of translation is inevitable in the teaching of foreign languages. As it is known, education of language consists of a few concepts such as listening, reading, writing, and speaking. Researches and experience in education of foreign languages, cause to arise an another concept. This concept, undoubtedly is translation. It is known that translation is a transfer process of a foreign work to an another language by the condition that the meaning is protected. In the 20th century, especially last ten years, Turkish translators who have a broad experience in translation of classical Russian literature have began to translate the Russian works successfully. In many of these translations national spirit, national psychology, the manner of heroes are being given truly. However, sometimes there are mistakes that are observed in these translations. In translation courses of the teaching programs of Russian language and literature, we think that the use of works of Russian poets and writers, the writers of Turkish peoples that have been writing in Russian language (Chingiz Aitmatov, Olzhas Suleymanov, and likewise) as a translation material is useful. In the education of language, the students by comparing their translations with literary translation of the same work may grasp the translation problems more better and develop their translation skill successfully.
\end{abstract}

Keywords: literary translation, teaching of Russian, comparative translation, Chingiz Aitmatov

\section{Introduction}

As it is known, the main purpose of translation lectures is to enrich the word treasure of students with new words and expressions. On the other hand, translation helps to develop the predisposition of students to the foreign language. Generally, it is not possible to correct and uniform translation without being adapted to the original language deeply and without being cognized the genuine national entirely. There are some differences of esthetic translation from other translations. The most important difference is style. The feature of esthetic style is to carry the aim of preserving moral purity and entrust translation apart from its esthetic mission. In literary translation, it is not sufficient to know only the foreign language. Here, special artifice, we can even say that having the ability of writing talent, being noble artists, to know the format of language and word and to give the esthetic characters realistically needed. It is required to know the culture reflected in original, its national spirit, 
all characteristics of its life style, its traditions and customs, its national beliefs, its accepted practices, and the psychology and mentality of its public. The Russian poet A. S. Pushkin (1799-1837) named the translators as "postal horse of civilization". One of the most important thing in translation is to take the following factors into consideration: epithets, comparisons, metaphors, expressions, proverbs, the new and slang words that author used, the names and surnames that have a meaning, toponims, antroponims, dialects, quotations, and the morphologic and syntax structure in the original language. In this point of view, the translator must approach carefully to every word, sentence, and even every line.

The use of literary translations as a tool of teaching Russian more broadly and deeply to Turkish students who are learning Russian Language is of benefit in a large scale. In translation lessons, we ask students to investigate translations (translated into Turkish language) in some parts of works belongs to Russian or writers using Russian language with the original text and to analyze the same translations by comparing them with their translations. In this point of view, we use the original and translated books of Chingiz Aitmatov who writes many of his books in Russian language and who is also a famous writer of Turkish community and draw attention among Turkish students.

\section{The Properties of Chingiz Aitmatov's Works}

The distinguished problems (human spirit, how a humans morale should be, how light can found its way, nature, and human interacts, the current situation of human, etc.,) in Aitmatov's (1970, 1972, 1973, 1988, 2008) works contain national and universal features. Aitmatov evaluated this dependences by using national legends, epics in learning narratives. Also according to him, the Kyrgyz-Turkish mythology takes an important place (Irmak, 2010; Kolesnikoff, 1999; Tumanov, 1996). Aitmatov searches the solution of contemporary problems in mythology, which is an experience of the tried history of all generations from ancient times to today and he often find the solution. One of the preoccupied problems for Aitmatov is the nature and human interaction problem. According to him, the nature around us is an existence that is suitable for easy use. The nature which gives everything to human can also take it back. Everything on earth surface is dependent with each other. Unfortunately, the civilization exploits and destructs ruthlessly everything which is natural and still unfortunately, human cannot understand that the harm he has given to the nature will turn to himself. The problems that Aitmatov wants to find are solutions by the use of Turkish philosophy and historical psychology generally have universal feature. In the works of the writer, the images of animals which are integral parts of nature take important places. Animals also have destinies like as humans. In many of the works of Aitmatov as in the Manas epic, we coincide with animal images. All of these animals are carriers of characters. Like humans they also have destinies, happiness, and grief.

We have to record that Aitmatov knew deeply Russian culture, language, philosophy of that language, and psychology. Though being a user of Russian language, his creativeness was always based on the core of Kyrgyz-Turkish background. His characters like all humans' in our world, although reflect the same universal emotions when smiling, crying and although their form of thinking, said songs, and lament are in Russian language, here we hear a national Turkish soul. The language of Aitmatov is not that simple. Also according to him there occur many problems in the translation process. First of all, the morphologic structure of Turkish and Russian languages is different. Turkish belongs to agglutinative languages and Russian belongs to flective 
languages. These are informal differences. These differences make the translation process complicated. On the other hand, The literary language of Chingiz Aitmatov is very complicated: rich and deep ideas, complex and hard sentences. Sometimes, any event that is conveyed by the writer changes to internal monologue of hero or a speech that is spoken in present tense is given as spoken in past tense. So this complicates the translators' job.

Taking all of these into account before starting to translate a special preparation of students is needed. From this point of view before starting to translate by making students closely familiar with the creativeness of the writer, we give the literary style and language specifications of the writer to students.

\section{About the Last Novel of Chingiz Aitmatov}

One of the striking fact about the mode of the writer is the last novel of the writer whose name is When The Mountains Fall (Eternal Bride) (Aitmatov, 2006). In the novel, the question of where the human being is come from and where he is going to is handled in world that humans are coming and going. The writer shows that everything - humans, animals, or plants — is the same as a sand grain in terms of dependency to faith and being a tiny particle over against the nature. In the novel we see that in the contemporary world, the spiritual values are mercilessly decomposed, the struggle between the old values and newly formed relationships is started. Terefore, we can see that both humans and animals are toys in the hand of the faith. The hero of the work Arsen Samanchin grew up with soviet spirit, very honest as a character, love human and nature, talented, is an independent journalist. He believed in the "perestroika" that Gorbachov established, joined to his mob, called everybody to renew the socialism with all types of spirituality in the journal "Spirituality" which was deviated from its purpose in market economy. Although he still standed to say that his discourse lonely like a crane that was cut from its crew after the mob were dispersed, he did not lost his belief and the belief of future. This spirit was given to him by the opera artificer Aydana Samarova and the desire of writing a new opera and the desire of studying together on the legend "Eternal Bride". But like a hurricane and a storm, the new economical system suddenly grabbed people, and it swept away everything and the majority could not resist to it. Also Aydana could not resist to this, she gave herself to the new "nuvorish" (upstarts)—oshondoys (exactly like that) and Arseni forget "Eternal Bride". Arsen Samachin could not struggle with the Oşondoys (exactly like that) since their arms were not mind, logic, and spirit but money. The humiliated, insulted Arsen found out the solution, thinking of finding his rival and then killing him. However, it is not the way of people who have the purity of spirit and have the ideal of the "Eternal Bride" like Arsen and thousands of intellectuals similar to Arsen. Arsen could not find a place in this new society and finally the mountains that carry the fundamentals of his thoughts took him into its bosom and he became eternal. The other hero of the work, the snow panther Jaabars lived the same faith similar to Arsen. Jaabars was a leader, mighty and invincible among the panthers once upon a time who had lost his influence, humiliated on the front of a panther whose ears were crooked, the female of him left him and so being desolated, he could not stand for these, he preferred to live in the inns of the inaccessible summits of Deity (Tyanshan) mountains and lost his life there. Both humans and animals become eternal in their primordial dwellings-inn. However, the writer did not so pessimistic in the novel. He created the copy of stunning "Eternal Bride" in the foundations of Kirgiz-Turkish legend. Eternal Bride took the crimes of humans upon herself when walking around world and called humans to spiritual purity. The object of the work is this: The Eternal Bride and her beauty, purity, and innocence will save the humanity and world. 


\section{The Investigation of the Translations of the Novel When the Mountains Fall}

There are two different translations of the novel from different publication houses. The translation publicated by "Elips Kitap" publication house was translated by Prof. Dr. Ahmet Pirverdioglu and the name of translation is Ebedi Gelin. Dağlar Ylkıldı̆g Zaman (after I. Translation) (Aitmatov, 2010), the translation publicated by "Ufuk Kitap" publication house was translated by Güzel Sarıül Şonbayeva and the name of the translation is Dağlar Devrildiğinde. Ebedi Nişanlı (after II. Translation) (Aitmatov, 2007). By investigating these two translations, we can conclude that the two translators know well about the Russian language and the life style of Russians. The translators maintain the style of the book, the style of expression, the genuine language of Chingiz Aitmatov and national features. By taking the characteristics of language of Chingiz Aitmatov into account, we can conclude that the translators accomplish a hard task. In the translation lessons when analyzing the two translations with original text in a comparative way, we come across with some situations that generate questions. The object of this report is not a criticism of the translations; its aim is to draw attention to the obstacles that occur in the process of translation in language teaching. In this point of view, by analyzing some of the words, expressions, and sentences that generate questions in translation, we learn to give more reasonable counterparts from our point of view:

“...и рыси на них фырчат и шипят, вроде как не признают троюродных сородичей.”

(1) “... vaşaklar fıslıyor ve tıslıyor, sanki kendi kuzenlerini tanımak istemiyorlardı” (Aitmatov, 2010, p. 10).

(2) "Vaşaklar bu hemcinslerini tanımazlıktan gelir; onlara hırlar, tıslarlar" (Aitmatov, 2007, p. 8).

In the first translation the sentence was given almost the same as it was given in the original, but the words in Russian "троюродные сородичи" translated as "kuzenler" in the first translation and "hemcinsler" in the second one. Whereas, here the word "троюродные сородичи" has the meaning "uzak akraba".

"И помни: прижми хвост, пока не поздно."

(1) "Henüz geç olmadan aklını başına devşir" (Aitmatov, 2010, p. 36).

(2) “... ve geç olmadan kuyruğunu topla” (Aitmatov, 2007, p. 43).

For us, "Ve unutma: ne kadar ki geç değil kuyruğunu kıs" is more appropriate.

"пахарь от СМИ"

(1) “... o, ... suradan bir medya amelesi idi” (Aitmatov, 2010, p. 39).

(2) “... basın tarlasının sıradan bir işçisiydi” (Aitmatov, 2007, p. 46).

The first translation is more goodly, for the word "amele" and the word "hamal" can also be used.

“как послание свыше."

(1) "göklerden gönderilmiş bir mesaj gibi” (Aitmatov, 2010, p. 53).

(2) "bir merhamet mesaj1 olarak" (Aitmatov, 2007, pp. 62-63).

The counterpart of "как послание свыше" should be "ayet".

“... чтобы добыть для угощения почтенных гостей свежей дичи, а для дарения-звериных шкур.”

(1) “... aziz misafirlerine ikram etmek için av eti, hediye için ise hayvan postu getirmeye...” (Aitmatov, 2010, p. 61).

(2) “... saygın misafirlere etini ikram, postunu da hediye etmek üzere...” (Aitmatov, 2007, p. 73).

In the original, the words have the meanings “почтённие гости"-_saygın misafirler", “свежая 
дичь"- “taze avlanmış kuş eti". If in the first translation the word "saygın" instead of "aziz", then the first translation will be more close to the original than the second one.

To show the differences between the original and translations easily, we placed them in Table 1.

Table 1

The Differences Between the Original and Translations

\begin{tabular}{|c|c|c|c|}
\hline Original & I. Translation & II. Translation & Commentary \\
\hline ... и великая охота ждет... & $\begin{array}{l}\ldots \text { kanlı avlar1... } \\
\text { severlerdi. (s. 10) }\end{array}$ & $\begin{array}{l}\ldots \text { av partilerinde gönüllerini } \\
\text { eğlendirirler ... (p. } 8 \text { ) }\end{array}$ & [onları] muhteşem av bekliyordu... \\
\hline $\begin{array}{l}\text { Прихоти судьбы } \\
\text { непредсказуемы... }\end{array}$ & $\begin{array}{l}\text { Kaderin neler yapacağını } \\
\text { kestiremezsin } \\
\text { (p. 13) }\end{array}$ & $\begin{array}{l}\text { Kaderin cilveleri önceden } \\
\text { kestirilemez ... (p. 12) }\end{array}$ & $\begin{array}{l}\text { The II. Translation is more } \\
\text { appropriate }\end{array}$ \\
\hline $\begin{array}{l}\text {... барсиху и кривоухого } \\
\text { баловня-соперника ...” }\end{array}$ & $\begin{array}{l}\text {... dişisine ve eğri kulaklı } \\
\text { talihli rakibine ...(p. 13) }\end{array}$ & $\begin{array}{l}\text {... kadim hayat arkadaşının } \\
\text { yırtık kulaklıyla ... (p. 13) }\end{array}$ & $\begin{array}{l}\text {.. dişisine ve eğri kulaklı şanslı } \\
\text { şımarık rakibine ... }\end{array}$ \\
\hline $\begin{array}{l}\text { тигроподобный пятнистый } \\
\text { царь высокогорья }\end{array}$ & $\begin{array}{l}\text {... yüksek dağların kaplana } \\
\text { benzeyen benekli kralı ... } \\
\text { (p. 14) }\end{array}$ & $\begin{array}{l}\text { Zirveleri karla kaplı dağların } \\
\text { kaplan görünüşlü çarı, } \\
\text { benekli ... (s. 14) }\end{array}$ & ... yüce dağların benekli sultanı. \\
\hline $\begin{array}{l}\ldots \text { попивая вино и } \\
\text { прислушиваясь к дежурной } \\
\text { музыке ... }\end{array}$ & $\begin{array}{l}\text {.. şaraptan } \\
\text { yudumlayarak ... (p. 18) }\end{array}$ & $\begin{array}{l}\text {... şarabını yudumlarken ... } \\
\text { (p. 18) }\end{array}$ & $\begin{array}{l}\text {... şaraptan yudumlayarak ve ifa } \\
\text { edilen yedek müziği dinleyerek... }\end{array}$ \\
\hline $\begin{array}{l}\text {... на своем вполне сносном } \\
\text { английском, освоенном в } \\
\text { московские годы учебы на } \\
\text { высших комсомольских } \\
\text { курсах для ведения борьбы с } \\
\text { империалистическим } \\
\text { Западом ... } \\
\end{array}$ & $\begin{array}{l}\text {... Moskova'da okuduğu } \\
\text { yillarda öğrendiği çok da } \\
\text { kötü olmayan } \\
\text { İngilizcesiyle... (p. } 20)\end{array}$ & $\begin{array}{l}\text { Moskova'da öğrencilik } \\
\text { yıllarında öğrendiği, hiç de } \\
\text { fena sayılmayan } \\
\text { İngilizcesiyle...(p. 20) }\end{array}$ & $\begin{array}{l}\text { Moskova'da, yüksek komsomol } \\
\text { kurslarında emperyalist Batı ile } \\
\text { mücadele etmek için ögrendiği hiç } \\
\text { de fena olmayan İngilizcesiyle... } \\
\text { (The meaning of the word } \\
\text { "komsomol" can be given at the } \\
\text { footnote) }\end{array}$ \\
\hline $\begin{array}{l}\text {.. в их честь звучали то } \\
\text { Вагнер, то Шопен, то } \\
\text { кто-нибудь еще из гениев. }\end{array}$ & $\begin{array}{l}\text {... onların şerefine Chopin } \\
\text { veya dahilerden birisinin } \\
\text { müziği çalıyordu. (p. 19) }\end{array}$ & $\begin{array}{l}\text {.. bunların onuruna Chopin } \\
\text { ya da aynı asrın dahilerinden } \\
\text { biri çalıyordu. (p. 20) }\end{array}$ & $\begin{array}{l}\text {... onların şerefine ya Vagner'in, ya } \\
\text { Chopin'in, ya da dahilerden birisinin } \\
\text { müziği seslendiriliyordu. } \\
\text { (In the both of the translations, the } \\
\text { word "Vagner" is not exist, the verb } \\
\text { is not translated correctly in terms of } \\
\text { meaning and time) }\end{array}$ \\
\hline $\begin{array}{l}\text { Ведь музыка - это хождение } \\
\text { к Богу, галактика духа. }\end{array}$ & $\begin{array}{l}\text { Ne de olsa müzik Tanrı'ya } \\
\text { doğru yürümedir, ruhun } \\
\text { evrenidir. (p. 19) }\end{array}$ & $\begin{array}{l}\text { Müzik vasıtasıyla Tanrı'ya } \\
\text { yaklaşır insan ve müzik ruhun } \\
\text { galaksisidir. (p. 20) }\end{array}$ & $\begin{array}{l}\text { Sahiden, musiki insanı Tanrı'ya } \\
\text { doğru götüren yoldur, ruhun } \\
\text { evrenidir. }\end{array}$ \\
\hline $\begin{array}{l}\text { Ты не думай, что погнал } \\
\text { меня в шею - и все! ... У } \\
\text { меня тоже есть свои ресурсы. }\end{array}$ & $\begin{array}{l}\text { Beni kovdun ve her şey } \\
\text { bitti diye düşünme. ... } \\
\text { Benim de kendime göre } \\
\text { imkanlarım var. (p. 24) }\end{array}$ & $\begin{array}{l}\text { Beni yakamdan tutup atmakla } \\
\text { her şeyin bittiğini sanma! ... } \\
\text { Benim de kendime göre } \\
\text { bağlantılarım var. (pp. 26-27) }\end{array}$ & $\begin{array}{l}\text { Beni kulağımdan tutup atmakla her } \\
\text { şeyin bittiğini sanma! ... Benim de } \\
\text { ak1l edemediğin / saklı kaynaklarım } \\
\text { var. }\end{array}$ \\
\hline $\begin{array}{l}\text {... душа его полыхала } \\
\text { лесным пожаром. }\end{array}$ & $\begin{array}{l}\ldots \text { içinde orman yangınları } \\
\text { vardı. (p. 35) }\end{array}$ & $\begin{array}{l}\text {... ruhu bir orman yangınında } \\
\text { alevleri arasında kalmış̧asına } \\
\text { yanıyordu. (p. } 38 \text { ) }\end{array}$ & $\begin{array}{l}\text {.. içi ateş düşmüş orman gibi cayır } \\
\text { cayır yanıyordu. }\end{array}$ \\
\hline $\begin{array}{l}\text { Кому из коммунальных } \\
\text { соседей какое могло быть } \\
\text { дело до того ... }\end{array}$ & $\begin{array}{l}\text {.. bu şehir komşularının } \\
\text { umurunda mıydı sanki? (p. } \\
\text { 36) }\end{array}$ & $\begin{array}{l}\text {.. kimin ve hangi komşunun } \\
\text { umurunda olabilirdi ki? } \\
\text { (p. 42) }\end{array}$ & $\begin{array}{l}\text {... kommunal komşularından kimin } \\
\text { umurunda olabilirdiki? } \\
\text { (The meaning of the word } \\
\text { "kommunal" can be given at the } \\
\text { footnote) }\end{array}$ \\
\hline $\begin{array}{l}\text {... будь он с детства отдан } \\
\text { музыкальной учебе, а не } \\
\text { гонял бы аильных лошадей в } \\
\text { горах ... }\end{array}$ & $\begin{array}{l}\text {... çocukken dağlarda köy } \\
\text { atlarını kovalamak yerine } \\
\text { müzik okuluna } \\
\text { verilseydim ... (p. 20) }\end{array}$ & $\begin{array}{l}\text {... çocukluk yıllarımda } \\
\text { köydeki atların peşinden } \\
\text { koşturmak yerine müzik } \\
\text { okuluna gitseydim ...(p. 21) }\end{array}$ & $\begin{array}{l}\text {.. çocukluğundan dağlarda ail } \\
\text { atlarını kovalamaktansa müzik } \\
\text { eğitimi alsaydı ... }\end{array}$ \\
\hline $\begin{array}{l}\text {... выступать в печати } \\
\text { музыкальным чаятелем и } \\
\text { театральным критиком ... }\end{array}$ & $\begin{array}{l}\text {... basında bir müzik ve } \\
\text { tiyatro eleştirmeni olarak } \\
\text { yazılar yazmak ... (p. 20) }\end{array}$ & $\begin{array}{l}\text {... medyada müzik ve tiyatro } \\
\text { eleştirmenliği yapmak ve } \\
\text { müziğe duyduğu hayranlığı } \\
\text { anlatmak... (p. 21) }\end{array}$ & $\begin{array}{l}\text {... basında müzik hayranı/özlemcisi } \\
\text { ve tiyatro eleştirmeni olarak ... }\end{array}$ \\
\hline
\end{tabular}


Furthermore, it should be noted that before comparative translating from the parts of the work, the words and expressions which exist in the text are separately selected and their meanings are broadly given to students. From this point of view, we can give the following word and expression as an example:

гнать в шею (dismiss)

деньги листопадом (a blank cheque)

ломавая музыка (heavy music)

масскультура (mass culture)

просить подаяния (begging)

прямой эфир (live)

свежая дичь (fresh wildfowl)

судьбоносный момент (faithfull moment)

требовать мзду (demanding bribes)

уличные торжищи (street trade)

умыкать женщину (kidnapping a women)

Aitmatov uses many Kyrgyz-Turkish words in the his Russian works. In this point of viewing his last novel is not an exception. For example, in this work the word "аил" that Aitmatov used often was translated into "köy" in both translations. Whereas, the writer intentionally did not used the word "село" or "деревня" which is the Russian counterpart of the word "köy" with the aim of reflecting the national spirit. In the translation we recommend our students to use these words as given original. The writer generally gives the Russian counterparts of the words which have Kyrgyz-Turkish origin in text. We can give the following words as an example:

аильный мулла—ail mollası (köy imamı), барымта—barımta (fidye, rehine için ödenen para), бий—biy (bey), джезде—cezde (enişte), дуйне—duyne (dünya), жоулоо—jouloo (yayla), казан—kazan (tencere), тенгри-tengri (tanrı), токмо-акын-tokmo-akın (duygularını döken ozan, içten okuyan aşık), тункукук— tunkukuk (gece baykuşu), тюмен аил—tümen ail (aşağı ail, aşağı köy), узенгилеш—uzengileş (üzengi gibi, üzengiye benzer), укмуш-ukmuş (harika, çok güzel, pek iyi), ханзада—hanzada (hanzade), шамалбаш—şamalbaş (kafasında rüzgarlar esen birisi).

As a result, we see that both of the translations printed in Turkish of the novel When The Mountains Fall (Eternal Bride) that we use translation of Russian language lessons which are generally preserve the work's level of idea and art. We see that the translation of Ahmet Pirverdioglu is more stuck to the original text and Güzel Sarıül Şonbaeva remains more free in the translation. Furthermore, for some reasons or other despite of the word, expressions even passages exist in the original text in both of the translations are dismissed.

As we have mentioned before, here our object is not to criticize the translations but to point out some obstacles that we face in translation lessons when using these translations as a tool.

\section{Conclusions}

It is helpful to make comparison of literary Turkish translations of novels of Chingiz Aitmatov in Russian with the originals in the process of education of Russian Language to Turkish students in translation lectures. In this process, the students can see their mistakes by comparing their translations with literary translations. 
Furthermore, this method not only enriches the Russian thesaurus of the students but also prompts them to read the original of literary works.

\section{References}

Aitmatov, Ch. (1970). Farewell Gul'sary. London: Hodder \& Stoughton Ltd..

Aitmatov, Ch. (1972). The white ship. London: Hodder \& Stoughton Ltd..

Aitmatov, Ch. (1973). Tales of mountains and steppes. Moscow: Progress Publishers.

Aitmatov, Ch. (1988). The time to speak out. Moscow: Progress Publishers.

Aitmatov, Ch. (2006). When the mountains fall (Eternal Bride)—Druzhba Narodov (No. 7) (Когда Падают Горы (Вечная невеста)—Дружба Народов (№7)). Moscow: Druzhba Narodov Publishers.

Aitmatov, Ch. (2007). When the mountains fall (Eternal affianced) (Dağlar devrildiğinde (Ebedi nişanlı)) (1st ed.). G. S. Şonbaeva (Trans.). Istanbul: Ufuk Kitap.

Aitmatov, Ch. (2008). Mother earth and other stories. London: Faber and Faber.

Aitmatov, Ch. (2010). Eternal bride (When the mountains fall) (Ebedi gelin (Dağlar yikildiği zaman)). A. Pirverdioğlu (Trans.). (5th ed.). Ankara: Elips Kitap.

Irmak, Y. (2010). From national to universal: Folkloric elements which are reflected to Chingiz Aitmatov's "Forever Engaged When the Mountains Collapsed". Karadeniz-Black See, 2, 123-140.

Kolesnikoff, N. (1999). Myth in the works of Chingiz Aitmatov. Lanham, M.D.: University Press of America.

Tumanov, V. (1996). Mythic cycles in Chingiz Aitmatov's spotted dog running along the seashore. Canadian Slavonic Papers, $38(1-2)$. 